\title{
FAKTOR YANG MEMPENGARUHI TINGKAT KEPATUHAN IBU HAMIL DALAM SKRENING HIV/AIDS
}

\author{
Visia Luh Gita \\ Institut Ilmu Kesehatan Strada Indonesia
}

visialuhgita21@gmail.com

\begin{abstract}
ABSTRAK
Human immunodeficiency virus (HIV) dan Acquired immune deficiency syndrome (AIDS) merupakan salah satu sorotan dalam pencapaian target Millenium Development Goals (MDGs). Ibu hamil dengan HIV akan berisiko menularkan kepada bayinya. Tes HIV merupakan gerbang pembuka status HIV yang sangat penting dilakukan pada ibu hamil. Ada banyak faktor yang mempengaruhi kenapa ibu hamil banyak yang tidak melakukan test HIV/AIDS pada masa kehamilannya, ini tentunya merupakan tantangan terberat bagi pemerintah khususnya petugas kesehatan, untuk itu perlu adanya kerjasama yang baik anatara pemerintah, petugas kesehatan dan lintas sektor terkait dalam pencapaian target Millenium Development Goals (MDGs).

Kata kunci : Tingakat kepatuhan ibu hamil, Skrening HIV/AIDS, Target MDGs Pemerintah
\end{abstract}

\section{Latar Belakang}

Saat ini pemerintah sedang gencar-gencarnya dalam menurunkan angka kejadian penularan HIV/AIDS pada ibu hamil dengan program Development Goals (MDGs), untuk itu diperlukannya kerjasama antara pemerintah, petugas kesehatan dan lintas sector terkait agar program pemerintah ini bias berjalan dengan baik. Ibu atau bayi dengan HIV/AIDS berpeluang besar untuk menyumbang angka kematian ibu maupun bayi yang sangat menentukan derajat kesehatan masyarakat di suatu negara. Meski penelitian pada 20032010 di 8 provinsi Indonesia menunjukkan bahwa prevalensi atau angka HIV/AIDS pada ibu hamil tergolong rendah, ini tidak membuat HIV/AIDS pada ibu hamil menjadi masalah kecil. Justru menjadi momok yang sangat menakutkan terhadap keberlangsungan hidup. Pertama kali kasus HIV/AIDS pada anak di Indonesia terjadi di Bojonegoro, Jawa Timur, setelah seorang ibu pengidap HIV melahirkan bayi perempuan. Hingga 2018, pengidap HIV pada anak dan remaja (di bawah 19 tahun) terus bertambah, mencapai 2.881 orang. Jumlah tersebut meningkat dari tahun 2010, yaitu sebanyak 1.622 anak terinfeksi HIV. 


\section{Kasus/Masalah}

Dari latar belakang diatas kita bisa melihat bahwa dari tahun ke tahun angka penularan HIV/AIDS dari Ibu ke bayinya semakin meningkat, Untuk itu pemerintah sedang menggerakkan program penurunan angka kejadian penularan HIV/AIDS terhadap ibu hamil dengan cara pemeriksaan laboratorium HIV/AIDS untuk seluruh ibu hamil tanpa terkecuali. Tetapi, yang menjadi kendala adalah belum semua ibu hamil sadar bahwa pentingnya memeriksakan laboratorium terkait HIV/AIDS .

\section{Tinjauan Pustaka}

HIV (Human Immuno-Devesiensi) adalah virus yang hanya hidup dalam tubuh manusia, yang dapat merusak daya kekebalan tubuh manusia dengan menginfeksi dan menghancurkan sel CD4. Semakin banyak sel CD4 yang dihancurkan, kekebalan tubuh akan semakin lemah, sehingga rentan diserang berbagai penyakit. Infeksi HIV yang tidak segera ditangani akan berkembang menjadi kondisi serius yang disebut AIDS . AIDS (Acguired Immuno-Deviensi Syndromer) adalah kumpulan gejala menurunnya gejala kekebalan tubuh terhadap serangan penyakit dari luar. AIDS adalah stadium akhir dari infeksi virus HIV. Pada tahap ini, kemampuan tubuh untuk melawan infeksi sudah hilang sepenuhnya.

Data dari United National Joint Programme for HIV and AIDS (2013) menyatakan bahwa pada tahun 2012 sekitar 35,3 juta orang di dunia hidup denganHIV/ AIDS. Pada tahun yang sama jumlah kasus baru HIV di dunia mencapai 2,3 juta kasus dan kasus kematian karena AIDS mencapai 1,6 juta kasus. Menurut laporan Kemenkes RI (2013), sejak 1 Januari 2013 sampai dengan September 2013 kejadian HIV mencapai 20.413 orang. Kejadiantertinggi HIV terjadi pada kelompok usia 25-49 tahun dengan persentase 73,4\%. Perilaku seksual berisiko pada heteroseksual menjadi faktor risiko tertinggi yaitu sebesar 45,6\% untuk HIV dan 78,4\% untuk AIDS. Perbandingan jumlah penderita laki-laki dan perempuan adalah 1:1 untuk HIV dan 2:1 untuk AIDS. Jumlah penderita HIV/ AIDS perempuan semakin bertambah seiring dengan meningkatnya penularan pada perilaku 
seksual tidak aman pada laki-laki yang kemudian menularkan HIV kepada pasangan seksualnya. Selain itu, penularan HIV dari ibu yang terinfeksi HIV kepada bayinya cenderung meningkat seiring dengan meningkatnya jumlah perempuan yang terinfeksi HIV. Pada triwulan III tahun 2013 yang menunjukkan faktor risiko penularan HIV dari ibu ke anak sebesar $4,3 \%$, meningkat $0,2 \%$ dari laporan Kemenkes tentang HIV triwulan II tahun 2013. Penularan HIV dari ibu ke anak dapat tersebut dapat terjadi pada saat kehamilan, persalinan, dan menyusui.

IBU hamil yang mengidap human immunodeficiency virus (HIV)/AIDS berpotensi menularkan penyakitnya kepada bayi saat dilahirkan. Oleh karena itu, penting untuk mengetahui status HIV/AIDS pada ibu hamil guna mencegah penularan tersebut. Untuk melakukan pencegahan, pemerintah sudah mencanangkan program skrining HIV/AIDS pada ibu hamil di rumah sakit (RS) milik pemerintah. Sayangnya, hingga saat ini cakupan skrining tersebut masih rendah. Berdasarkan data Kementerian Kesehatan (Kemenkes), pada 2018 tes HIV pada ibu hamil hanya sekitar 13,38\% (761.373) dari total jumlah ibu hamil di Indonesia sebanyak 5.291.143 orang. Dari jumlah yang menjalani tes tersebut, yang diketahui positif HIV tercatat 2.955 orang. Sementara itu, yang mendapatkan terapi obat ARV (antiretroviral) dalam upaya menekan jumlah virus (VL), lebih sedikit lagi, yakni hanya 893 ibu hamil. Direktur Kesehatan Keluarga Kemenkes Eni Gustina mengungkapkan, ada sejumlah kendala yang membuat belum semua ibu hamil melakukan skrining HIV. Kendati sudah 98\% ibu hamil melakukan pemeriksaan kehamilan oleh bidan dan di fasilitas kesehatan. Kendalanya, antara lain tidak semua ibu hamil bersedia melakukan pemeriksaan darah di laboratorium. Selain itu, ada ibu hamil yang memeriksakan kehamilan di bidan desa dan tidak semua ibu hamil mau dibawa ke puskesmas yang punya fasilitas laboratorium untuk pemeriksaan darah. Ia lebih lanjut mengatakan, terdapat sejumlah tantangan lain yang dihadapi dalam upaya menurunkan prevalensi orang dengan HIV di Indonesia, yakni minimnya pengetahuan masyarakat mengenai HIV, stigma yang berkembang, dan diskriminasi. Menurut Eni, stigma negatif bukan hanya muncul dari masyarakat, melainkan juga dari tenaga kesehatan. Sebagian besar masyarakat, lanjutnya, belum tahu 
tentang penyebab dan cara penularan HIV/AIDS. "Bahkan, ada rumah sakit yang menolak membantu pasien HIV untuk melahirkan dan merujuknya ke rumah sakit provinsi.

\section{Pembahasan}

Dari data diatas bisa kita telaah bahwa kenapa ibu hamil banyak yang tidak memeriksakan status HIV/AIDS nya dikarenakan tidak semua ibu hamil bersedia melakukan pemeriksaan darah di laboratorium. Selain itu, ada ibu hamil yang memeriksakan kehamilan di bidan desa dan tidak semua ibu hamil mau dibawa ke puskesmas yang punya fasilitas laboratorium untuk pemeriksaan darah. Terdapat sejumlah tantangan lain yang dihadapi dalam upaya menurunkan prevalensi orang dengan HIV di Indonesia, yakni minimnya pengetahuan masyarakat mengenai HIV, stigma yang berkembang, dan diskriminasi. Dalam hal ini dapat disimpulkan bahwa pendekatan kepada masyarakat tentang pentingnya pemeriksaan HIV/AIDS sangatlah penting mengingat bahaya yang bias ditimbulkan baik penularan kepada bayinya, penularan kepada petugas kesehatan maupun kepada pasangan. Ini merupakan tantangan terberat khususnya untuk petugas kesehatan di karenakan tidak semua masyarakat mempunyai pengetahuan yang baik tentang bahayanya penyakit ini, dan tinngi rendahnya tingkat pengetahuan masyarakat tidak terlepas dari faktor sosial ekonomi dari masyarakat. Untuk itu pentingnya koordinasi dengan lintas sektor terkait seperti petugas kelurahan beserta kader-kader desa, akan sangat membantu agar program Millenium Development Goals (MDGs) bias tercapai.

\section{Kesimpulan}

Dari berbagai jurnal dan teori diatas dapat disimpulkan bahwa orang dengan tingkat pengetahuan dan sosial ekonomi yang rendah banyak yang tidak bersedia untuk melakukan skrening HIV/AIDS. 


\section{Daftar Pustaka}

1. Aini, L.N. 2017. Pilihan Kontrasepsi Perempuan Penderita HIV. Midwifery Science Journal , 1(1), pp. 130-41.

2. Ariningtyas, N. 2017. Kendala Program PPIA pada Antenatal Care. Jurnal Kesehatan Samudra Ilmu, 8.

3. Ditjen PP \& PL. 2014. Statistik HIV AIDS di Indonesia.Jakarta:aidsindonesia.or.id.

4. Halim, Y..S.B.\&.K.A.. 2016. Faktor-faktor yang Berhubungan dengan Perilaku Ibu Hamil dalam Pemeriksaan HIV di Wilayah Kerja Puskesmas Halmahera Kota Semarang. Jurnal Kesehatan Masyarakat (e-Journal).

5. Isni, K. 2016. Dukungan Keluarga, Dukungan Petugas Kesehatan dan Perilaku Ibu HIV dalam Pencegahan Penularan HIV/AIDS dari Ibu keBayi. Jurnal Kesehatan Masyarakat, 11(2), pp.96-104.

6. Kemenkes RI. 2012. Pedoman Pencegahan Penularan HIV dari Ibu ke Anak. Jakarta:Kemenkes RI.

7. Liem, A. \& Adiyanti, M.J. 2013. Bidan Cantik:Psychoeducation on HIV and AIDS to Improve the Service Quality of Midwifes at Yogyakarta Pulic Health Center. HIV and AIDS Review, 12(1),pp. 1-28.

8. Mikrajab, M.A. \& Rachmawati, T. 2016. Analisis Kebijakan Implementasi Antenatal Care Terpadu Puskesmas di Kota Blitar. Buletin Penelitian Sistem Kesehatan, 19(1), pp. 42-53.

9. Moleong, L.J. 2017. Metodologi Penelitian Kualitatif.Bandung: Rosdakarya.

10. Ratnasari, D. 2017. Analisis Pelaksanaan Sistem Rujukan Berjenjang Bagi Peserta JKN di Puskesmas X Kota Surabaya. Jurnal Administrasi Kesehatan Indonesia.

11. Utarini, A. 2007. Metode Penelitian Kualitatif di Bidang Kesehatan. Yogyakarta: FK UGM.

12. Wahyuni, S. 2017. Hubungan antara Pengetahuan HIV/ AIDS dengan Sikap Penolakan terhadap Penderita HIV. Jurnal Kesehatan Reproduksi

13. WHO. 2009. Pelayanan Kesehatan Anak di Rumah Sakit. Jakarta: WHO Indonesia. 